\title{
Teachers' and Supervisors' Perceptions of Supervision Practices in Public Secondary Schools in East Shoa Zone, Oromia Region
}

\author{
Tadesse Abera 1
}

${ }^{1}$ Jimma University, Ethiopia

\begin{abstract}
The purpose of the study was to explore perceptions of public secondary school teachers and supervisors in East Shoa Zone in Oromia Region regarding school supervision practices. A descriptive survey research approach was used in this study. Teachers, secondary school supervisors assigned by woreda education offices, school principals, and department heads were included as sources of data. Purposive sampling, stratified and simple random sampling techniques were employed to select the zone, sample schools, and 256 participants for the study. The survey questionnaire consisted of 30 items, clustered around five dimensions of supervisory practice such as instruction (7 items), communication(6 items), staff development (7 items), evaluation (4 items), and classroom observation (6 items) were used by the researcher. Mann-Whitney U test - to identify if any significant differences exist between teachers' and supervisors' opinion on supervision practice dimension was deemed appropriate to analyse the survey data and were conducted using SPSS version 21. The findings from this study revealed that teachers and supervisors differed significantly on perceptions of different dimensions of supervisory practices such as instruction, communication, staff development, and evaluation. Classroom observation dimension of supervision practice was the only area, in which teachers' and supervisors' perceptions were very similar, i.e., teachers and supervisors seem to perceive these practices positively.
\end{abstract}

Keywords: Perceptions; Supervision practices; Public secondary schools

\begin{abstract}
Introduction
Glickman, Gordon, and Ross-Gordon (2001:56) describe the term Supervision as a common vision "that is developed collaboratively and brought into reality together. It forms connections that focus organizational and individual goals, objectives and efforts into an overarching strategy". Capacity is built into the system as the supervisor encourages employees to reach their full potential, and helps to develop interpersonal relationships and a productive organizational culture (Dessler, Munro \& Cole, 2011). These outcomes are achieved by daily informed supervision. The supervisor, by definition, is someone who assists, guides, directs, and oversees the people that he/she is managing, however there is much more to being a supervisor than simply overseeing the jobs that people are doing (Langton, Robbins \& Judge, 2011). In order to be a successful supervisor, it is important that one understands not only their own beliefs towards education and approaches towards individuals and groups, but that they also understand the beliefs and approaches of their supervisees.
\end{abstract}

\begin{abstract}
The way teachers view the supervision that they are undergoing and think about it is very important in the outcomes of the supervision process. Supervision is an interactive process that depends on the source of supervision, the supervisor, and the teacher. Therefore, knowing their opinions and expectations about the supervisory practices is important to implementing successful supervision (Firth, 1997). Furthermore, comparing teachers' perceptions with the supervisors' perceptions will help in identifying the areas of disagreement, which, in turn, will help in improving the way these practices are introduced and avoid any potential conflict.
\end{abstract}

For decades, the field of supervision has been suffering from unfriendly and unstable relations between teachers and supervisors (Pool, 1994; Sullivan \& Glanz, 2000). Among the reasons is the different ways of seeing or perceiving things that take place at school as part of the supervisory activities. How supervisors should behave while working with teachers was the focus of most of the discussion about the field of supervision, and was a main drive for developing the different supervision models.

This article is published under the terms of the Creative Commons Attribution License 4.0

Author(s) retain the copyright of this article. Publication rights with Alkhaer Publications.

Published at: http://www.ijsciences.com/pub/issue/2017-04/

DOI: 10.18483/ijSci.1219; Online ISSN: 2305-3925; Print ISSN: 2410-4477 
Different models produced different practices. The aim was to reach for the best methods by which supervisors could best improve the teachers' performance and provide them with the needed assistance. To achieve this aim supervisors usually employ several supervisory practices.

There is a pressing need to know how supervisors view their performance while working with teachers. Simultaneously, there is a similar need to know how teachers view their supervisors' performances (Firth, 1997). Comparing these two views and tracing the areas of agreement and the areas of disagreement is an essential step in the process of any improvement endeavor. As observed by Ukeje et al. (1992), perceptual difference could lead to perceptual distortion whereby teachers would have wrong impressions about the supervisors who are supposed to be their partners in the education system. This could impact negatively on the achievement of educational objectives.

\section{Purpose of Supervision}

According to Nolan and Hoover (2006: 6), supervision should not be used as a means of judging a "teacher's competence and performance". In contrast, supervision should be used to help teachers meet the goals of the state and district for its students (Nolan \& Hoover, 2006). Within the literature addressing the purpose of supervision, two main themes were evident. The main purposes of supervision were identified as helping to (a) meet the needs of teachers and (b) guide the teachers in meeting the needs of students ( Black, 2004; Ebmeier, 2003; Glickman, 2002;). Marshall (2005) purported that once supervision was done effectively, teachers' skills and knowledge would dramatically improve, which would result in high student achievement.

In addition to monitoring the learning process, supervision should be used to ensure that the students were experiencing a rigorous curriculum (Aseltine et al., 2006). Through observation, peer coaching, walkthroughs, and other forms of supervision, the teachers' ability to meet the needs of all the learners without 'dumping down' the information would become evident. With the help of supervisors, teachers could get help learning how to cater to the needs of each unique student while helping the students attain the next level of achievement.

In order to ensure that teachers were meeting the learning process and goals of a rigorous curriculum, supervision should be used to help teachers grow professionally (Nolan \& Hoover, 2006). In order to help teachers grow professionally, the administrator must identify the teachers' needs and then equip them with the skills to meet these needs (Ebmeier, 2003; Glickman, 2002; Marshall, 2005). As the instructional leader, the supervisor cannot be in every classroom every single minute of the instructional day. By equipping teachers with the tools to make critical decisions about student learning, the supervisors were changing the perception of their role from being just the inspector to a leader who supervised but trusted the ability of the staff to become more effective (Ebmeier, 2003; Nolan \& Hoover, 2006).

\section{Dimensions of Supervisory Practice}

A renewed interest in clarifying and delineating the work of school supervisors has emerged in light of the decentralization and restructuring of schools. Researchers and practitioners have attempted to shed light on the functional areas of supervisors by either defining supervisory competencies or supervisory task areas (Harris, 1985, Bailey, 1985). One extensive research effort to delineate the job of the school supervisor is found in Pajak's study (1989) to identify and prioritize "dimensions" of supervisory practice. From this research, 12 highly recognized dimensions were identified. These dimensions, with their brief descriptions, are presented below.

Community Relations - Establishing and maintaining open and productive relations between the school and its community;

Staff Development - Developing and facilitating meaningful opportunities for professional growth; Planning and change - Initiating and implementing collaboratively developed strategies for continuous improvement;

Communication - Ensuring open and clear communication among individuals and groups throughout the organization;

Curriculum - Coordinating and integrating the process of curriculum development and implementation;

Instructional Program - Supporting and coordinating efforts to improve the instructional program; Service to Teachers - Providing materials, resources, and assistance to support teaching and learning; Observing and Conferencing - Providing feedback to teachers based on classroom observation;

Problem Solving and Decision Making - Using a variety of strategies to clarify and analyze problems and to make decisions;

Research and Program Evaluation - Encouraging experimentation and assessing outcomes; Motivating and Organizing- Helping people to develop a shared vision and achieve collective aims; 
Personal Development - Recognizing and reflecting upon one's personal and professional beliefs, abilities, and actions (Pajak, 1990:6).

\section{Statement of the Problem}

Ethiopia showed significant progresses in education. Access at all levels of the education system increased at a rapid rate. Disparities decreased through a more than average improvement of the situation of the disadvantaged and deprived groups and of the emerging regions (MoE, 2012; World Bank, 2013). However, the quality aspect particularly in the general education sub-sector including improvement of students achievement through consistent focus on the enhancement of learning and teaching process and the transformation of the school into a motivational learning environment are still remained a challenge (MoE,2012).

If quality education is seriously desired in schools so that standard of education in our schools can be highly improved, school supervision must therefore be accorded high priority. Through inspection and supervision, the supervisors assist in improving classroom instructions because teachers are made more competent and efficient, parents are satisfied with the performance of their children, children are motivated to work harder in order to achieve the required standard, hence in the long run, the goal of education is achieved (De Grauwe, 2007).

However, Over the past decade, research has indicated that supervision process was not as effective as it should be; which eventually resulted in poor student achievement (Black, 2004; Daresh, 2006; Nolan \& Hoover, 2008). This was critical because research had documented evidence of the direct connection between educator quality and student achievement (Nolan \& Hoover, 2008).

Studies on school supervision in Ethiopia have generally been conducted on the very limited basis of one educational stakeholder view. For example Alemayehu (2008), conducted survey research in 10 secondary schools of Addis Ababa and came up with the conclusion that teachers have negative perception towards instructional supervision. Hence, it is considered important that supervision practice in secondary schools in East Shoa Zone, Oromia Regional State should be assessed from the viewpoint of teachers and supervisors who are among the major partners in carrying out education in the system.

The purpose of the study was to explore perceptions of public secondary school teachers and supervisors in East S hoa Zone, Oromia Region regarding school supervision practices.

\section{The research questions}

This study was guided by the following research questions:

1. Is there a difference among East Shoa Zone public secondary schools' teachers and

supervisors in perceptions of instruction dimension of supervision practice?

2. Is there a difference between supervisors'

perceptions of their communication practice

and the ratings of such practices by teachers?

3. Is there a difference between teachers and supervisors in perceptions of staff development practice?

4. Is there a difference between East Shoa Zone public secondary schools' teachers and

supervisors in perceptions of evaluation dimension of supervision practice?

5. Is there a difference between supervisors'

perceptions of their classroom observation

practice and the ratings of such practices by teachers?

\section{Objectives of the study}

The overall purpose of this study was to determine perceptions of teachers and supervisors regarding supervisory practices of secondary schools in East Shoa Zone in Oromia Region.

Specific objectives

1. To determine the differences between East Shoa

Zone public secondary teachers' and supervisors' perceptions of instruction.

2. To determine the differences between East Shoa

Zone public secondary teachers' and supervisors' perceptions of communication.

3. To identify the differences between East Shoa

Zone public secondary teachers' and supervisors' perceptions of staff development.

4. To identify the differences between East Shoa

Zone public secondary teachers' and supervisors' perceptions of evaluation.

5. To determine the differences between East Shoa

Zone public secondary teachers' and supervisors' perceptions of classroom observation.

\section{Research Design and Methodology \\ The Research Design}

This study described the supervision practices within public secondary schools. The research questions associated with this study would seek to gather information that describes the perceptions of teachers and supervisors regarding the supervision practices. According to Lauer (2006), the research design must match the research questions; therefore, a descriptive 
survey approach to conducting this study was the most appropriate for answering the mentioned research questions.

\section{Target Population}

The population of this study comprised of all public secondary school supervisors, principals, vice principals, and department heads in East Shoa Zone Secondary Schools (grades $9-12$ ).

According to information obtained from East Shoa Zone Education Office (2015) there were 13 woredas with 27 public secondary schools. There were 996 secondary school teachers, 54 principals, 324 department heads, and 27 secondary school supervisors (1 supervisor assigned by WEO for each school).

\section{Samples and Sampling Techniques}

In order to establish the sample for the study, the researcher obtained 2015 statistical data on the number and names of woredas, schools, number of teachers and school-based supervisors from East Shoa Zone Education Office. Different sampling techniques were employed to get the different samples used in this study. These are explained in the sections that follow.

\section{The Zone}

The study zone is one of the eastern Oromia zones. The zone combines both rural and urban characteristics. Although full generalization may be limited, the findings that were drawn from data collected in this zone might be an indication of what is happening in other zones in the region. The zone is thus purposively sampled due to its characteristics that are representative of the other zones in the region as well as its easy access to the information required for the design of this study.

\section{Schools}

To make the sample schools justifiable, 6 public secondary schools were selected on the basis of purposive sampling technique. The rationale for choosing these schools was that they have high concentration of academic staff and they are the schools that have more supervisory experience than the other younger and newly opened schools.

\section{Teachers}

With regard to respondent sampling, teachers were chosen to serve as the main data sources. Accordingly, out of the total 420 teachers in the sample secondary schools, $172(41 \%)$ were selected using stratified random sampling technique. Gorard (2003:68) opines that stratified sampling technique allows the researcher to select cases in proportion to one or two characteristics in the population to enhance quality sample. In light of this, the researcher considered two characteristics: general secondary schools (grades $9 \& 10$ ) and preparatory schools (grades $11 \& 12$ ) to ensure that each individual teacher in the population has an equal opportunity to be selected in the sample. The sample was distributed in proportion to the number of teachers in each secondary school. Each school shared from the sample the same percentage that it represents from the whole teacher population.

\begin{tabular}{|c|c|c|c|}
\hline \multirow{2}{*}{ Name of the School } & \multirow{2}{*}{$\begin{array}{c}\text { Teacher } \\
\text { Population }\end{array}$} & \multicolumn{2}{|c|}{ Respondents } \\
\cline { 3 - 4 } & & Teachers & Supervisors \\
\hline Awash Melkasa Secondary School & 53 & 22 & 12 \\
\hline Boset Secondary School & 75 & 30 & 15 \\
\hline Chefe Donsa Secondary School & 55 & 23 & 14 \\
\hline Goro Secondary School & 122 & 51 & 15 \\
\hline Merti Secondary School & 35 & 14 & 14 \\
\hline Mojo Secondary School & 80 & 32 & 14 \\
\hline Total & $\mathbf{4 2 0}$ & $\mathbf{1 7 2}$ & $\mathbf{8 4}$ \\
\hline
\end{tabular}

Table 1: Participants of the Study

\section{Supervisors}

For this study, secondary school supervisors assigned by Woreda Education Offices, school principals, and department heads were all considered as secondary school supervisors. Accordingly, out of 72 department heads, 66 were selected using simple random sampling while 12 school principals and 6 assigned supervisors were selected using purposive sampling technique. 


\section{Instrument}

For the purpose of this study, based on Pajak's model (1990), the survey questionnaire consisted of 30 items, clustered around five dimensions of supervisory practice such as instruction (7 items), communication(6 items), staff development (7 items), evaluation (4 items), and classroom observation (6 items) were used by the researcher. Secondary school teachers and supervisors were asked to respond to each survey item using a five-point Likert-type rating scale. This scale indicated the extent to which each subject agreed or disagreed with each questionnaire item. The use of the questionnaire in this study would help to get an overview about teachers' and supervisors' perceptions regarding supervision practice in secondary schools in East Shoa Zone.

\section{Validity and Reliability of the instrument}

As indicated earlier, survey questionnaire was used in this study. Regarding the validity of the questionnaire, a pilot study was carried out with 10 teachers and supervisors working in secondary schools, who looked at the item formulation and the appropriateness of the items (their face validity). This pilot study produced recommendations for changes, which were incorporated into the survey to ensure it was readable, unambiguous, and focused on the data needed. Reliability analyses of the questionnaire items indicated that all five sub-scales were reliable (instruction Cronbach's $\alpha=0.91$; communication Cronbach's $\alpha=0.88$; staff development Cranach's $\alpha=0.82$; evaluation Cronbach's $\alpha=0.77$; classroom observation Cronbach's $\alpha=0.73$ ). This test was used to assess the reliability of the subscales to ensure the internal consistency of the elements (George \& Mallery, 2009). "The closer the alpha is to 1.00 , the greater the internal consistency of items in the instrument being assessed" (George \& Mallery, 2009:223).

\section{Data analysis Method}

The number of factors was considered in order to determine the choice of a statistical test to analyze the data. In order to test if there are statistically significant differences between groups, it is essential to first establish if the data follows a normal (Gaussian) distribution. If the data follows a normal distribution pattern then parametric tests are appropriate for statistical analysis. However, if the data is not normally distributed then less powerful non-parametric tests, or distribution-free methods, ought to be adopted in order to maintain the validity and accuracy of the data. It is also important to classify variables according to their level or scale of measurement. There are certain statistical analyses which are only meaningful for data which are measured at certain measurement scales (i.e., nominal, ordinal, interval or ratio). In addition to these factors, the appropriate method for statistical analysis depends on the number of groups (two versus more than two) involved in the comparison as criterion.

After considering the aforementioned factors in relation to the data obtained for this study, MannWhitney $U$ test - to identify if any significant differences exist between two groups' opinion on supervision practice dimensions was deemed appropriate to analyse the survey data and were conducted using SPSS version 21.

\section{Results}

The results are presented here as findings under each research question. Since the instrument of this study was divided into 5 subscales, the researcher tried to explore the teachers' and supervisors' perceptions of supervisory practices in each sub-scale, and find out if there are any differences among them. These subscales explored teachers' and supervisors' perceptions of supervisory practices in the following areas:

1. Instruction, item 1 to 7 in the original questionnaire

2. Communication, item 8 to 13

3. Staff development, item 14 to 20

4. Evaluation, item 21 to 24

5. Classroom Observation, item 25 to 30

\section{Perceptions of Instruction}

The first basic question of the study was:

Is there a difference among East Shoa Zone public secondary schools' teachers and supervisors in perceptions of instruction dimension of supervision practice?

Table 2: Mann-Whitney U Test for Perception of Instruction Dimension Supervision Practices

\begin{tabular}{|l|r|l|l|}
\multicolumn{1}{|c}{ Ranks } \\
\begin{tabular}{|l|rc|l|}
\hline Occupation & N & $\begin{array}{l}\text { Mean } \\
\text { Rank }\end{array}$ & $\begin{array}{l}\text { Sum of } \\
\text { Ranks }\end{array}$ \\
\hline Teacher & 172 & & \\
Instruction & 84 & 109.71 & 18869.50 \\
Supervisor & 256 & 166.98 & 14026.50 \\
Total & & & \\
\hline
\end{tabular}
\end{tabular}


Test Statistics ${ }^{\mathbf{a}}$

\begin{tabular}{|l|r|}
\hline & Instruction \\
\hline Mann-Whitney U & 3991.500 \\
Wilcoxon W & 18869.500 \\
Z & -5.835 \\
Asymp. Sig. (2- & .000 \\
tailed) & \\
\hline
\end{tabular}

a. Grouping Variable: Occupation

As shown in Table 2, in order to address the first research question, mann-whitney $U$ test was calculated to determine whether there was any statistically significant difference in the perce- ptions of teachers and supervisors regarding instruction dimension of supervision practice. An alpha level (p) of .05 was set for this analysis. A statistically significant difference was found between teachers and supervisors $(\mathrm{U}=3991.500, p=.000)$ in East Shoa Zone secondary schools in relation to the perception of instruction dimension of supervisory practice.

\section{Perceptions of communication}

The second basic question of the study was: Is there a difference between supervisors' perceptions of their communication practice and the ratings of such practices by teachers?

Table 3: Mann-Whitney U Test for Perception of Communication Dimension Supervision Practices

\begin{tabular}{|l|r|l|l|}
\hline \multicolumn{1}{|l|}{ Ranks } \\
Occupation & $\mathbf{N}$ & $\begin{array}{l}\text { Mean } \\
\text { Rank }\end{array}$ & $\begin{array}{l}\text { Sum of } \\
\text { Ranks }\end{array}$ \\
\hline $\begin{array}{l}\text { Teacher } \\
\text { Communication } \\
\text { Supervisor }\end{array}$ & 84 & 114.38 & 19673.00 \\
Total & 256 & 157.42 & 13223.00 \\
\hline
\end{tabular}

Test Statistics ${ }^{\mathrm{a}}$

\begin{tabular}{|l|c|}
\hline & Communication \\
\hline Mann-Whitney U & 4795.000 \\
Wilcoxon W & 19673.000 \\
Z & -4.385 \\
Asymp. Sig. (2- & .000 \\
tailed) & \\
\hline
\end{tabular}

a. Grouping Variable: Occupation

Table 3 presents the Mann-Whitney U Test statistics for the perceptions of communication-related supervision practices. It shows that a statistically significant difference was found between teachers and supervisors $(\mathrm{U}=4795.000, p=.000)$ in East Shoa Zone secondary schools pertaining to the perception of communication dimension of supervisory practices.

\section{Perceptions of Staff Development}

The third basic question was:

Is there a difference between teachers and supervisors in perceptions of staff development practice?

Table 4: Mann-Whitney U Test for Perception of Staff Development Dimension of Supervision Practices

\begin{tabular}{|l|r|l|l|}
\multicolumn{4}{|c|}{ Ranks } \\
\hline Occupation & $\mathbf{N}$ & $\begin{array}{l}\text { Mean } \\
\text { Rank }\end{array}$ & $\begin{array}{l}\text { Sum of } \\
\text { Ranks }\end{array}$ \\
\hline $\begin{array}{l}\text { Teacher } \\
\text { Staff Development } \\
\text { Supervisor }\end{array}$ & 84 & 112.00 & 19264.00 \\
Total & 256 & 162.29 & 13632.00 \\
\hline
\end{tabular}

Test Statistics ${ }^{\text {a }}$

\begin{tabular}{|l|c|}
\hline & \multicolumn{1}{|c|}{$\begin{array}{c}\text { Staff } \\
\text { Development }\end{array}$} \\
\hline Mann-Whitney U & 4386.000 \\
Wilcoxon W & 19264.000 \\
Z & -5.130 \\
Asymp. Sig. (2- & .000 \\
tailed) & \\
\hline
\end{tabular}

a. Grouping Variable: Occupation

As can be seen from Table 4, a Mann-Whitney U Test was calculated to examine the difference in the perceptions of teachers and supervisors regarding staff development dimension of supervision practice. A statistically significant difference was found between teachers and supervisors $(\mathrm{U}=4386.000, p=$ $.000)$.

\section{Perception of Evaluation}

The fourth basic question was:

Is there a difference between East Shoa Zone public secondary schools' teachers and supervisors in perceptions of evaluation dimension of supervision practice?

Table 5: Mann-Whitney U Test for Perception of Evaluation Dimension of Supervision Practices 
Teachers' and Supervisors' Perceptions of Supervision Practices in Public Secondary Schools in East Shoa Zone, Oromia Region

\begin{tabular}{|l|r|l|l|}
\multicolumn{4}{c}{ Ranks } \\
\hline Occupation & N & $\begin{array}{l}\text { Mean } \\
\text { Rank }\end{array}$ & $\begin{array}{l}\text { Sum of } \\
\text { Ranks }\end{array}$ \\
\hline $\begin{array}{l}\text { Teacher } \\
\text { Staff Development } \\
\text { Supervisor }\end{array}$ & 172 & 144.79 & 12162.00 \\
Total & 256 & 120.55 & \\
\hline
\end{tabular}

Test Statistics ${ }^{\mathrm{a}}$

\begin{tabular}{|l|c|}
\hline & $\begin{array}{c}\text { Staff } \\
\text { Development }\end{array}$ \\
\hline Mann-Whitney U & 5856.000 \\
Wilcoxon W & 20734.000 \\
Z & -2.481 \\
Asymp. Sig. (2- & .013 \\
tailed) & \\
\hline
\end{tabular}

a. Grouping Variable: Evaluation

As Table 5 presents, in order to address the fourth basic research question, a Mann-Whitney U test was utilized to examine the difference in the perception of teachers and supervisors with regard to evaluation dimension of supervision practice sub scale. A statistically significant difference was found $(\mathrm{U}=$ 5856.000, $p=.013$ ) between teachers and supervisors.

\section{Perception of Classroom Observation}

The fifth basic research question was:

Is there a difference between supervisors' perceptions of their classroom observation

practice and the ratings of such practices by teachers?

Table 6: Mann-Whitney U Test for Perception of

Classroom observation Dimension of Supervision

Practices

\begin{tabular}{|c|c|c|c|}
\hline \multicolumn{4}{|c|}{ Ranks } \\
\hline Occupation & $\mathbf{N}$ & $\begin{array}{l}\text { Mean } \\
\text { Rank }\end{array}$ & $\begin{array}{l}\text { Sum of } \\
\text { Ranks }\end{array}$ \\
\hline Teacher & 172 & 125.40 & 21569.00 \\
\hline Classroom & 84 & & \\
\hline Observn. & & 134.85 & 11327.00 \\
\hline & 256 & & \\
\hline Total & & & \\
\hline
\end{tabular}

Test Statistics $^{\mathrm{a}}$

\begin{tabular}{|l|c|}
\hline & $\begin{array}{c}\text { Staff } \\
\text { Development }\end{array}$ \\
\hline Mann-Whitney U & 6691.000 \\
Wilcoxon W & 21569.000 \\
Z & -.961 \\
Asymp. Sig. (2- & .336 \\
tailed) & \\
\hline
\end{tabular}

a. Grouping Variable: Classroom Observation

In order to address the fifth basic research question, Mann-Whitney U Test was utilized. As can be seen from Table 6, the test shows that there was no statistically significant difference between teachers' and supervisors' perception $(\mathrm{U}=6691.000, p=.336)$ pertaining to classroom observation dimension practices.

\section{Discussion}

A. Perception of Instruction

This was the first subscale for instruction-related supervisory practice. The findings of this study indicated that perceptions of the instruction related supervisory practices differ between teachers and supervisors. The supervisors have shown a relatively positive perception than teachers in this regard. This suggests that supervisors in North Shoa Zone put less emphasis on

instruction related supervisory related activities from the perspectives of teachers.

B. Perceptions of Communication

This study could also found out that a statistically significant difference existed between the perceptions of teachers and supervisors pertaining to the communication dimension of supervisory practices. Supervisors perceived communication more positively than teachers. This means that communication dimension is where the largest number of teachers disagree

with current practices. Communication is a vital part of the supervision practice, and the results speak to their belief in its importance. Effective communication is the life blood of an instructional organization (Mcnamara, 2011). Ensuring open and clear communication throughout the school is imperative, and supervisors might consider whether their current methods for communication are reaching all teachers within the school.

The literature on supervisory communication supports the contention that supervisory communication behaviors are directly linked to organizational effectiveness variables, such as job satisfaction and productivity (Koermer, et al., 1993). Studies have also reported that there is a positive relationship between the quality of organizational 
communication and job satisfaction and performance (Schanke, 1990).

C. Perceptions of Staff Development

Staff development is one of the main functions of the instructional supervisors (Pajak, 1990). Part of the supervisors' work with teachers is to arrange professional development programs to help in teachers' professional growth.

The staff development subscale was intended to measure the teachers' perceptions of the practices that supervisors do at school that contribute to the teachers' growth. The result of the study showed that there is a statistically significant difference between teachers' and supervisors' perceptions of the staff development dimension of supervision practices. Supervisors perceived these activities more positively than teachers.

D. Perceptions of Evaluation

Analysis of findings in this study revealed that in East Shoa Zone secondary schools, there is significant difference between teachers' and supervisors' perception of evaluation dimension of supervisory practice. The findings of this study show that teachers positively perceive evaluation than supervisors. In East Shoa Zone secondary schools, as the findings suggest, evaluation as dimension of supervisory practice is existent from the stand point of teachers.

This might indicate that teachers view evaluation overemphasized while supervisors may aware that overemphasizing evaluation is less effective in working with teachers.

\section{E. Perception of Classroom observation}

This study also revealed that there was no statistically significant difference between teachers' and supervisors' perception pertaining to classroom observation dimension supervision practices. This is the only area of the supervisory practices that the teachers' and supervisors' perceptions were very similar. In general, teachers and supervisors seem to perceive these practices positively.

\section{Conclusions}

Results from the survey were analyzed using MannWhitney $U$ Test to determine if a statistically significant difference existed between perceptions of East Shoa Zone public secondary schools' teachers and supervisors regarding supervisory practices. It was determined that a difference did exist for four dimensions. The four dimensions are: Instruction; Communication; Staff Development; and Evaluation. The results of these four supervisory practice dimensions' tests indicate that supervisors positively perceive than teachers do. The only dimension not found to have statistical significance difference was Classroom observation dimension. This means that teachers and supervisors positively perceive this supervisory practice dimension.

\section{References}

I. Acheson, K.A., \& Gail, M.D. (2003). Clinical supervision and teacher development: Preservice and inservice applications (5th ed.). NY: John Wiley \& Sons, Inc.

II. Acheson, K.A., \& Waite, D.E. (1998). Foundations in supervision. In F. Gerald \& E. Pajak

III. (Eds.), Handbook of research on school supervision (pp. 177-180). NY: Simon and Schuster Macmillan.

IV. Anderson, G. (2000). Fundamentals of Educational Research. New York: Routledge.

V. Anderson, R.H. \& Snyder, K.J. (1998). Functions of school supervision. In F. Gerald, \&

VI. E. Pajak (Eds.), Handbook of research on school supervision (pp. 341-373). NY:Simon and Schuster Macmillan.

VII. Andrews, R. L., Basom, M. R., \& Basom, M. (1991), Instructional leadership: Supervision that makes a difference. Theory into Practice, 30, 97-101.

VIII. Badiali, B. J. (1998). Teaching of supervision. In F. Gerald \& E. Pajak (Eds.), Handbook of

IX. research on school supervision (pp. 957-967). NY: Simon and Schuster Macmillan.

X. Basit, T.N. (2010). Conducting Research in Educational Contexts. London: Continuum.

XI. Blase, J., \& Blase, J. (2004). Handbook of instructional leadership: How successful principals

XII. promote teaching and learning (2nd ed.). Thousand Oak, California: Corwin Press.

XIII. Blumberg, A. (1980). Supervisors \& teachers: A private cold war. Berkeley: McCutchan.

XIV. Bogdan, R.C., and Biklen, S.K. (1998). Qualitative Research for Education: An Introduction to Theory and Methods. Boston: Allyn and Bacon.

XV. Bogdan, R.C., and Biklen, S.K. (1992). Qualitative Research for Education: An Introduction to Theory and Methods ( $2^{\text {nd }}$ ed.). Boston: Allyn \& Bacon.

XVI. Bryman, A. (1988). Quality and Quantity in Social Research. London: Allen and Unwin.

XVII. Bryman, A. (2001). Social Research Methods. Oxford: Oxford University Press.

XVIII. Carter, S. C. (2001). No Excuses: Lessons from 21 High-Performing, High-Poverty Schools. Washington D.C.: The Heritage Foundation.

XIX. Cogan, M. L. (1973). Clinical supervision. Boston: Houghton Mifflin.

XX. Clark, V.L.P. and Creswell, J.W. (2008). The Mixed Methods Reader. London: Sage.

XXI. Cohen, L., \& Manion, L. (1994). Research Methods in Education. London: Routeledge and Kegan Paul.

XXII. Cohen, L., Manion, L., \& Morrison, K. (2000). Research methods in education (5th ed.). New York, USA: Routledge Falmer.

XXIII. Cooley, V. E., \& Shen, J. (2003). School accountability and professional job responsibilities: A perspective from secondary principals. National Association of Secondary Principal's Bulletin, 87, 10-25.

XXIV. Creswell, J. (2002). Educational research: Planning, conducting, \& evaluating quantitative and qualitative research. Upper Saddle River, NJ: Merrill.

XXV. Denzin, N.K., and Lincoln, Y.S. (1998). Handbook of Qualitative Research, Volume 1 to 3. Thousand Oaks: Sage.

XXVI. Dessler, G., Munro, C.R., \& Cole, N.D. (2011). Management of human resources (3rd Can.ed.).

XXVII. Toronto, Canada: Pearson Prentice Hall. 
XXVIII. Dollansky, T. D. (1997). Rural Saskatchewan elementary $K-6$ teachers' perceptions of supervision and professional development. Unpublished master's thesis, Universityof Saskatchewan, Saskatoon, Saskatchewan, Canada

XXIX. Duffy, F. M. (1998). The ideology of supervision. In F. Gerald \& E. Pajak (Eds.), Handbook of research on school supervision (pp. 181-199). NY: Simon and Schuster Macmillan.

XXX. Ebmeier, H. (2003). How supervision influences teacher efficacy and commitment: An

XXXI. investigation of a path model. Journal of Curriculum \& Supervision, 18(2), 110-141.

XXXII. Firth, G. R. (1997). Governance of school supervision. In Gerald Firth \& Edward Pajak (Eds.), Handbook of Research on School Supervision. New York: Macmillan.

XXXIII. Fuhrman, S. H. \& Odden, A. (2001). A Kappan special section on school reform. Phi Delta Kappan, 83, 59-62.

XXXIV. Fullan, M. (2002). Leadership and sustainability. Principal Leadership, 3, 14-17.

XXXV. Gage, N. (1989). The paradigm wars and their aftermath: A "historical" sketch of research and teaching since 1989. Educational Research, 18, 4-10.

XXXVI. Gall, M. D., Borg, W. R., \& Gall, J. P. (1996). Educational research: An introduction. White Plains, NY: Longman.

XXXVII. Garmston, R. J., Lipton, L. E. \& Kaiser, K. (1998). The psychology of supervision. In F. Gerald

XXXVIII. \& E. Pajak (Eds.), Handbook of research on school supervision (pp.242 - 286). NY:

XXXIX. Simon and Schuster Macmillan.

XL. Gay, L. R. (1996). Educational research: Competencies for analysis and application. Englewood: Merrill, Prentice Hall.

XLI. Geertz, C. (1973). Thick Description: Toward an Interpretive Theory of Culture. In The

XLII. Interpretation of Cultures: Selected Essays. New York: Basic Books.

XLIII. Glatthorn, A. A. (1997). Differentiated Supervision. Washington(2nd ed.). Association for

XLIV. Supervision \& Curriculum Development.

XLV. Glickman, C. D. (1981). Developmental supervision: Alternative practices for helping teachers

XLVI. improve instruction. Alexandria, VA: Association for Supervision and Curriculum

XLVII. Development.

XLVIII. Glickman, C. (1990). Supervision of instruction: A developmental approach ( 2 ed.). Boston, MA: Allyn $\&$ Bacon.

XLIX. Glickman, C. D. (1985). Supervision of instruction. Boston: Allyn and Bacon.

L. Glickman C.D, Gordon S.P. \& Ross-Gordon J.M. (2001). Supervision and Instructional

LI. Leadership: A Developmental Approach, 5th edn. Toronto, ON: Allyn and Bacon.

LII. Goldhammer, R. (1969). Clinical supervision: Special methods for the supervision of teachers. NY: Holt, Rinehart and Winston.

LIII. Goldhammer, R., Anderson, R. H., \& Krajewski, R. J. (1980). Clinical supervision. New York: Holt, Rinehart, Winston.

LIV. Gordon, S. P., \& Nicely, R. F. (1998). Supervision and staff development. In G. R. Firth \& E. F.

LV. Pajak (Eds.), Handbook of research on school supervision (pp. 801-841). New York:

LVI. Simon \& Schuster Macmillian.

LVII. Grant, B., M. (2005). Fighting for space in supervision: Fantasies, fairytales, fictions and fallacies. International
Journal of Qualitative Studies in Education, 18, (3), 337-354.

LVIII. Guba, E. G. \& Lincoln, Y. S. (1985). Fourth generation evaluation as an alternative. Educational Horizons, 63, 139-141.

LIX. Guba, E.G., and Lincoln, Y.S. (1994). Competing paradigms in qualitative research. In N.K.

LX. Haileselassie, W. (2001). Current expectations from educational supervision in the Ethiopian

LXI. system. Material presented for training of trainers workshop. Addis Ababa, Ethiopia:Ministry of Education.

LXII. Harris, B. (1998). Paradigms and parameters of supervision in education. In G. R. Firth \&

LXIII. E. F. Pajak (Eds.), Handbook of research on school supervision (pp.1-34). NY: Simon and Schuster.

LXIV. Hesse, M. (1980). Revolutions and Reconstructions in the Philosophy of Science. Bloomington: Indiana University Press.

LXV. Iwanicki, E. F. (1998). Evaluation in supervision. In F. Gerald \& E. Pajak (Eds.), Handbook of

LXVI. research on school supervision (pp.138-175). NY: Simon and Schuster Macmillan.

LXVII. Joshi, R.D. \& Verspoor, A. (2013). Secondary Education in Ethiopia: Supporting Growth and Transformation. Washington, DC: World Bank.

LXVIII. Koops, J. B. \& Winsor, K. A. (2005). Creating a professional learning culture through faculty evaluation. Journal of Education, 186, 61-70.

LXIX. Kosmoski GJ (1997) Supervision. Mequon, WI: Stylex.

LXX. Langton. N., Robbins, S.P., \& Judge, T.A. (2011). Fundamentals of organizational behaviour $\left(4^{\text {th }}\right.$ Can. ed.). Toronto, Canada: Pearson Prentice Hall.

LXXI. Lincoln, Y., \& Guba, E. G. (2000). Paradigmatic Controversies, Contradictions and Emerging confluences. In N. K. Denzin \& Y. Lincoln (Eds.), Handbook of qualitative research (pp. 163- 214). London: Sage publications.

LXXII. Lovell, J., \& Wiles, K. (1985). Supervision for better schools. (5 th ed.). New Jersey: Prentice- Hall, Inc.

LXXIII. Maykut, P., and Morehouse, R. (1994). Beginning Qualitative Research-A Philosophic and Practical Guide. London: Falmer.

LXXIV. Maynard, M. (1994). Methods, Practice and Epistemology: The Debate about Feminism and

LXXV. Research. Researching Women's Lives from a Feminist Perspective. London: Taylor and Francis.

LXXVI. Ministry of Education, (1994). Educational Supervision Manual and Practice, Ethiopia: Addis Ababa, 4(4): 2126.

LXXVII. Mischler, E.G. (1986). Research Interviewing: Context and Narrative. Cambridge, MA: Harvard University Press.

LXXVIII. MOE (2012). Ethiopian National Professional Standards Framework for School Supervisors. Addis Ababa.

LXXIX. Nolan, J. F. \& Hoover, L. A. (2008). Teacher supervision \& evaluation: Theory into practice. (2nd edition). Hoboken, NJ: John Wiley \& Son.

LXXX. Oliva, P. F. \& Pawlas, G., E. (2001). Supervision for today's school (6th ed.). New York: John Wiley \& Sons, Inc.

LXXXI. Oliva, P.F. \& Pawlas, G.E. (2004) Supervision For Today's Schools, (7th ed.). Hoboken, NY:

LXXXII. Wiley. Pajak, E. (1990). Dimensions of supervision. Educational Leadership. 48 (1) pp. 7881.

LXXXIII. Peshkin, A. (2000). The nature of interpretation in qualitative research. Educational Researcher, 29(9), 59. 
Teachers' and Supervisors' Perceptions of Supervision Practices in Public Secondary Schools in East Shoa Zone, Oromia Region

LXXXIV. Pool, W. L. (1994). Removing the "super" from supervision. Journal of Curriculum and Supervision. 9 (3) pp. 284309

LXXXV. Prase, L. E. (2005). Refocusing the Purpose of Teacher Supervision. In F. W. English (Ed.), The sage handbook of educational leadership: Advances in theory, research, and practice (pp. 430-462). London: Sage Publications.

LXXXVI. Scriven, M. (1988). Evaluating teachers as professionals: The duties-based approach. In S. J.

LXXXVII. Stanley \& W. J. Popham (Eds.), Teacher evaluation: Six prescriptions for success (pp. 110-142). Alexandria, VA: Association for Supervision and Curriculum Development.

LXXXVIII. Seidman, I. (1990). Interviewing as Qualitative Research. New York: Teachers College Press.

LXXXIX. Sergiovanni, T. J. \& Starratt, R. J. (2002). Supervision: A redefinition (7th ed.). Boston: McGraw- Hill.

XC. Shulman, L.S. (1986). Those who understand: knowledge growth in teaching. Educational Researcher, 15(2), 4-14

XCI. Sparks, D. (2002). Designing powerful professional development for teachers and principals. Oxford, $\mathrm{OH}$ : National Staff Development Council.
XCII. Spradley, J.P. (1979). The Ethnographic Interview. New York: Holt, Rinehart \& Winston.

XCIII. Sullivan, S. \& Glanz, J. (2000). Alternative approaches to supervision: Cases from the field. Journal of Curriculum and Supervision. 15 (3), 21235.

XCIV. Teddlie, C., and Tashakkori, A. (2009). Foundations of Mixed Methods Research: Integrating

XCV. Quantitative and Qualitative Approaches in the Social and Behavioural Sciences. London: Sage.

XCVI. Ukeje, B. O., Akabogu, G. C. \& Ndu, A. (1992). Educational administration. Enugu: Fourth Dimension Publishing co., Ltd.

XCVII. Waite, D. (1995). Rethinking instructional supervision: Notes on its language and culture. London: The Falmer Press.

XCVIII. Walker, R. (1985). Doing Research: A Handbook for Teachers. London: Routledge.

XCIX. Zepeda, S. J. (2006). High stakes supervision: We must do more. International Journal of Leadership in Education, 9, (1), 61-73

C. Zepeda, S. J. (2007). Instructional supervision Applying tools and concepts (2"d ed.). Larchmont, NY: Eye

on Education. 